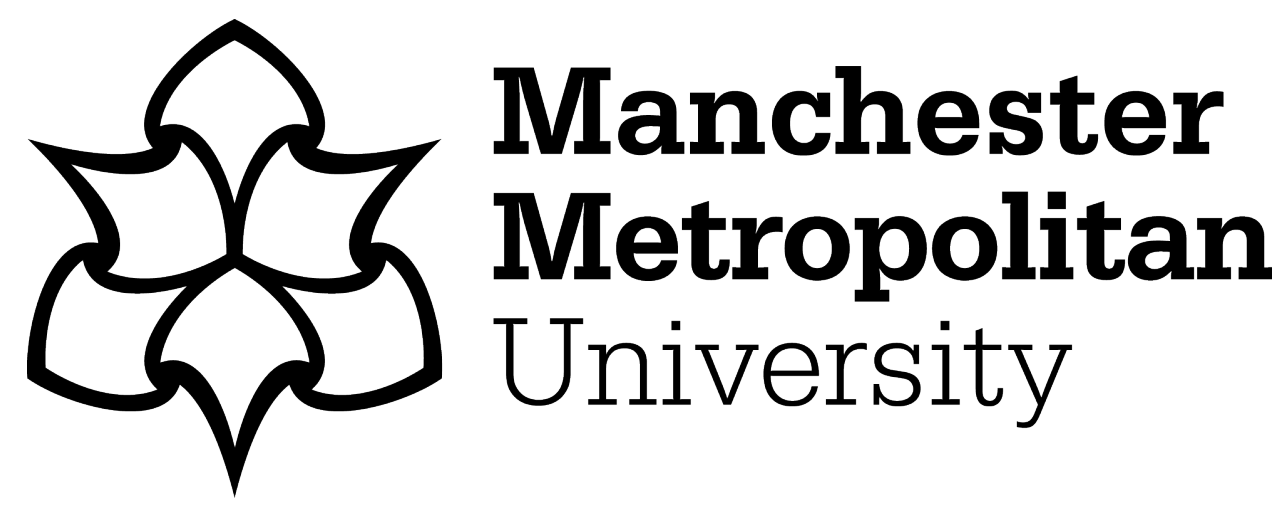

Giladi, Paul ORCID logoORCID: https://orcid.org/0000-0002-8934-3602 and Petherbridge, Danielle (2021) The Vulnerable Dynamics of Discourse. Royal Institute of Philosophy Supplement, 89. pp. 195-225. ISSN 1358-2461

Downloaded from: https://e-space.mmu.ac.uk/627866/

Version: Accepted Version

Publisher: Cambridge University Press (CUP)

DOI: https://doi.org/10.1017/S1358246121000151

Usage rights: Creative Commons: Attribution-Noncommercial-No Derivative Works 4.0

Please cite the published version 


\title{
The Vulnerable Dynamics of Discourse
}

\author{
PAUL GILADI AND DANIELLE PETHERBRIDGE
}

\begin{abstract}
In this paper, we offer some compelling reasons to think that issues relating to vulnerability play a significant - albeit thus far underacknowledged - role in Jürgen Habermas's notions of communicative action and discourse. We shall argue that the basic notions of discourse and communicative action presuppose a robust conception of vulnerability and that recognising vulnerability is essential for (i) making sense of the social character of knowledge, on the epistemic side of things, and for (ii) making sense of the possibility of deliberative democracy, on the political side of things. Our paper is divided into four principal sections. In Section 1, we provide a basic outline of Habermas on communicative action and discourse. In Section 2, we develop an account of vulnerability and communication in the context of speaker/hearer relations. We specifically focus on distorted communication, vulnerability and speech. In Section 3, we focus on elaborating epistemic pathologies in the context of epistemic oppression and testimonial injustice. In Section 4, we focus on explaining how Habermasian resources contribute to vulnerability theory, and how introducing vulnerability theory to Habermas broadens or deepens his theory of communication action and his discourse ethics theory.
\end{abstract}

\section{I have spread my dreams under your feet; Tread softly because you tread on my dreams W.B. Yeats}

\section{Communicative Action and Discourse}

Jürgen Habermas places significant philosophical as well as sociopolitical emphasis on the intrinsically social character of language: meaning, normativity, and knowledge are mediated by practices that are rooted in communicative action. ${ }^{1}$ For Habermas, communicative action is the type of action aimed at establishing consensus (i.e. mutual understanding) through the agonistic establishment of legitimate and valid norms for persons (i.e. language-using individuals). As Habermas frames it:

1 By 'normativity', we mean the general idea of obligations, justifications, and values.

doi:10.1017/S1358246121000151 C Crown Copyright, 2021. Published by Cambridge University Press in association with The Royal Institute of Philosophy and the contributors

Royal Institute of Philosophy Supplement 02021 


\section{Paul Giladi and Danielle Petherbridge}

The concept of communicative action presupposes language as the medium for a kind of reaching understanding, in the course of which the participants, through relating to a world, reciprocally raise validity claims that can be accepted or contested. (Habermas, 1984, p. 99)

Communicative action is not modelled on any kind of instrumentalised subject-object relationship and means-end framework. This is because communicative action is the variety of activity constituted by one of our knowledge-constitutive interests, ${ }^{2}$ namely communicative interests: the function of communicative action is to interpret and to bring about the intelligibility of concepts such as justice and goodness under public reason. Communicative action, therefore, is directed at ends-in-themselves and to realising an intersubjective relationship between agents as much as possible. Specifically, the norms structuring communicative action simultaneously concern three different kinds of validity claims - a) claims to truth; b) claims to sincerity (truthfulness), and c) claims to normative rightness. ${ }^{3}$ Tracing his intellectual lineage to Fichte's theory of recognition, ${ }^{4}$ G.H. Mead's pragmatist social psychology, and J.L. Austin's speech act theory, Habermas's theory of communicative action draws on the following claims from Fichte, Mead, and Austin respectively.

On the Fichtean side of things, the 'I' must 'posit' (Setzen) itself as an individual for the 'I' to be an individual. In order to posit itself as an individual, the 'I' must recognise itself as 'summoned' by another individual. The summons (Aufforderung) ${ }^{5}$ of another individual

2 Viz. Habermas (1973, p. 196; p. 308).

3 By 'normative rightness', we take Habermas to refer to intersubjectively and communicatively constituted forms of moral obligation and value orientations.

4 Crucially, what we have written here is not meant to either ignore or downplay the significance of Hegel's theory of recognition for Habermas's position. In his iconic essay 'Labour and Interaction: Remarks on Hegel's Jena Philosophy of Mind', Habermas identifies and lays out what he sees as Hegel's better conception of intersubjectivity than Fichte's. From Habermas's perspective, given that Hegel - much like Fichte - articulates the communicative normative content of modern ethical life in metaphysical ways, neglecting the pragmatic dimensions of language-use and communication, Hegel, at best, multiplies beyond necessity his development of a protoform of communicative rationality and action. Habermas construes his own postmetaphysical model as Hegelian without any 'metaphysical mortgages' (Habermas, 1987b, p. 316).

5 Aufforderung ranges from 'begging' (bitten) to 'demanding' (verlangen). 
limits the freedom of the 'I' out of respect for the freedom of the Other. ${ }^{6}$ Such a practice of mutual recognition between individuals is a necessary condition for the possibility of personhood. On the Meadian side of things, the practice of navigating one's way in a team/group by understanding the various roles and behavioural habits/associations of 'the generalised other' enables a person to develop self-consciousness, which involves the internalisation of socialising practices. ${ }^{7}$ Mead's well-known claim that individuation occurs through socialisation and his focus on both gestural and linguistic forms of interaction become central to Habermas's own theory. As Habermas writes:

I see the more far-reaching contribution of Mead in his having taken up themes [such] that ... individuation is pictured not as the self-realisation of an independently acting subject carried out in isolation and freedom but as a linguistically mediated process of socialisation ... Individuality forms itself in relations of intersubjective acknowledgement and of intersubjectively mediated self-understanding ... Mead will shift all fundamental philosophical concepts from the basis of consciousness to that of language. (Habermas, 1992, pp. 1528

In 53 thper 162) words, Habermas contends that Mead is credited with the foundational insight that language-use involves norms requiring discursive exchange, a variety of an I-thou relation, rather than the I-hey and/or I-it relation, and that the most basic linguistic unit is 'the relationship between ego's speech-act and alter's taking a position' (Habermas, 1992, p. 163).

On the Austinian side of things, Habermas claims that 'a turn to the pragmatics of language ... concedes primacy to world-disclosing language - as the medium for the possibility of reaching understanding, for social cooperation ... - over world-generating subjectivity' (Habermas, 1992, p. 153). ${ }^{9}$ Briefly put, Austin details three varieties of speech-acts, ${ }^{10}$ where the latter two are especially relevant for our concerns and for making sense of Habermasian communication (and discourse):

- Locutionary act: uttering the literal meaning (Bedeutung) of a statement - i.e. stating the pure semantic content of a proposition.

6 Viz. FNR (p. 31). Cf. Wood (2016, p. 83).

7 Viz. MSS (p. 154).

8 Cf. Taylor (1987, p. 13).

9 See also Habermas (1984, pp. 288-95); Habermas (1998, pp. 66-88). 


\section{Paul Giladi and Danielle Petherbridge}

E.g. 'It's rather nippy in Boston during winter' = 'it's very cold in Boston during the winter months'

- Illocutionary act: the intended meaning (Meinung) of the speaker in the utterance of a sentence, namely the assertive/directive/ commissive/expressive/declarative features of that sentence.

E.g. 'Jim, it's rather nippy in Boston during winter' = 'Jim, please consider taking a down-coat with you when you travel to Boston in the winter'.

- Perlocutionary act: the consequential effects of an illocutionary act.

E.g. After Sarah says 'It's rather nippy in Boston during winter' to Jim, Jim takes a down-coat with them when they travel to Boston in the winter.

Habermas himself identifies only illocutionary acts with communicative action, as, in his view, these acts are orientated to reaching mutual understanding and, in turn, such understanding is linked to reaching agreement and 'rationally motivated binding' or 'force' (Habermas, 1984, p. 278). For Habermas, then, 'communicative agreement has a rational basis [and] it cannot be imposed by either party, whether instrumentally through intervention in the situation directly or strategically through influencing the decisions of opponents' (Habermas, 1984, p. 287). In illocutionary acts a speaker partakes in communicative action in saying something such that she lets a hearer know she wants to be understood, in a perlocutionary act, the speaker aims to produce an effect on the hearer, and 'thereby brings about something in the world' (Habermas, 1984, pp. 288-89). Thus, according to Habermas's view, perlocutionary acts are associated with an intention and are considered a form of goal-directed action more generally. In Habermas's schema, perlocutionary acts then represent forms of strategic action given their intent is to bring about some particular end, rather than merely a form of communicative action directed toward mutual understanding.

Crucially, for Habermas, successful communication between agents involves the hearer being able to transparently (and non-coercively) grasp the reasons motivating the propositions put forward by the speaker:

We understand a speech act when we know what makes it acceptable. From the standpoint of the speaker, the conditions of acceptability are identical to the conditions for his illocutionary success. Acceptability is not defined here in an objectivistic sense, from the perspective of an observer, but in the performative attitude 
of a participant in communication. (Habermas, 1984, pp. 297-98; emphasis added)

The pragmatics of language do not only reveal how individuality is mediated through a complex process of socialisation. Rather, illocutionary acts also point to democratic potentialities. This is because '[w]henever the speaker enters into an interpersonal relationship with a hearer, he also relates himself as an actor to a network of normative expectations' (Habermas, 1992, p. 190). Linguistic practice involves not just grasping the norms of assertion, ${ }^{11}$ it also involves, to use Wilfrid Sellars's expression, knowing how to move in the space of reasons. ${ }^{12}$ Successful navigation in the space of reasons requires grasping the plurality of communicative inferential commitments and entitlements one has in the use of words.

Importantly, as mentioned above, for Habermas, the norms structuring communicative action simultaneously concern three different kinds of validity claims - claims to truth; claims to sincerity (truthfulness); claims to normative rightness -, which directly correspond to three different kinds of formal 'world':

[I]n communicative action a speaker selects a comprehensible linguistic expression only in order to come to an understanding with a hearer about something and thereby to make himself understandable. It belongs to the communicative intent of the speaker (a) that he perform a speech act that is right in respect to the given normative context, so that between him and the hearer an intersubjective relation will come about which is recognised as legitimate; (b) that he make a true statement ..., so that the hearer will accept and share the knowledge of the speaker; and (c) that he express truthfully his beliefs, intentions, feelings, desires, and the like, so that the hearer will give credence to what is said. (Habermas, 1992, pp. 307-308)

By engaging in illocutionary speech-acts - the 'bread and butter' linguistic practices of communicative action - (i) the intentional content of a speaker's propositions - i.e. to what the speaker is referring when they say things - is automatically directed to a shared world of agents. By virtue of, saying 'please consider', for example, the speaker is 'attempting to establish an interpersonal relation which the hearer will recognise as legitimate' (Niemi, 2005, p. 230); (ii) what the speaker is referring to in practices of communicative action is an accessible,

12 Viz. Sellars (1991, p. 169). 


\section{Paul Giladi and Danielle Petherbridge}

objective world; (iii) the speaker, just by virtue of performing an illocutionary speech-act ('Jim, you should seriously consider taking a down-coat with you when you travel to Boston in the winter') reveals a subjective world to the hearer. If Jim is to genuinely understand Sarah's advice, they must understand what it would mean to action her advice as well as understand that accepting Sarah's speech then commits them to take a down-coat with them when they travel to Boston in the winter.

Crucially, the emphasis on communication transforms the subject of experience from being voyeuristic to actively engaged. Habermas's position is, thus, allied with Kant's notion of pragmatic anthropology, which draws a distinction between die Welt kennen and Welt haben: "the expressions "to know the world" and "to have the world" are rather far from each other in their meaning, since one only understands the play that one has watched, while the other has participated in it' (APPV, [120], p. 4). This empowers human beings by regarding their communicative practices as authoritative, since it is only through successful discursive exchanges that one can meaningfully develop notions of autonomy and respect. As such, for a practical relation-to-self to be healthy requires progressive intersubjective relations, ones which engender and sustain autonomy and respect.

On the corresponding socio-political front, Habermas contends that all social processes are assessed with respect to how well (or invariably not) they foster communicability and the development of 'discourse', namely non-coercive arenas for the agonistic, public use of reason. As he writes, '[an] ego-identity can only stabilise itself in the anticipation of symmetrical relations of unforced reciprocal recognition' (Habermas, 1992, p. 188). Democracy and communication are necessarily tied together and mutually supporting: the failure to develop communicative action is a barrier to democracy in the public sphere, and the failure to develop democratic values is a barrier to communicative action.

In Habermas's schema, when communicative practices fail or break down, participants can turn to discourse. Discourse, for Habermas, involves the public testing of claims to universal normative validity; as such, discourse is central to his modern critical social theory, to the extent that his discourse theory is effectively the rational reconstruction of Kant's moral theory implicitly embedded in the theory of communicative action. For Habermas, discourse comprises two key principles: the Discourse Principle (D) and the Universalisation Principle (U).

(D) concerns '[ $\mathrm{j}]$ ust those action norms are valid to which all possibly affected persons could agree as participants in rational 
discourses' (Habermas, 1992, p. 107). In other words, valid norms are not extra-human dictates handed down to us. Rather, valid norms are, to use Robert Brandom's expression, (Brandom, 2002, p. 216)-outcomes of communicative action established and sustained by agents' intersubjective practices. These social achievements get their normative purchase by virtue of being assented to and acknowledged by a community of agents. Crucially, though, the practice of assenting to and acknowledging normative constraints and normative entitlements comprises determining 'the precise content of those implicit norms ... through a 'process of negotiation' involving ourselves and those who attribute norms to us' (Houlgate, 2007, p. 139). By virtue of being a process of negotiation, norms are never fixed but always subject to 'further assessment, challenge, defence, and correction' (Brandom, 1994, p. 647).

(U) concerns the formal, pragmatic procedural justification of moral norms based on (D). In effect, Habermas construes (U) as the rational reconstruction of Kant's supreme principle of morality in the Groundwork for the Metaphysics of Morals. As he writes,

[t]he Categorical Imperative is always already in the background here: the form of a general law legitimates the distribution of liberties, because it implies that a given law has passed the universalisation test and been found worthy in the court of reason. (Habermas, 1996, p. 120) ${ }^{13}$

Crucially, the Kantian universalisation test aims to establish which maxims and interests pass deliberative discursive articulation and challenge such that those maxims and interests are objectively valid (or universally and equally binding for any rational agent). By extension, democracy, for Habermas, is a constitutional state model structured in accordance with the principles of communicative action and discourse: the laws of a democratic constitutional state are legitimate insofar as we arrive at them through discursive practices that are wholly intersubjective and inclusive, since society can only be integrated peacefully in the long-run if social integration involves communicative action and discourse. ${ }^{14}$

In what immediately follows, we examine the vulnerability of speaking and communicating subjects in light of issues raised or neglected by Habermas's account of communicative action. We take vulnerability to be understood as a multifaceted concept, one that generally refers to our interdependence as human beings. Here

13 See also Habermas (1996, p. 153).

14 Viz. Habermas (2001). 


\section{Paul Giladi and Danielle Petherbridge}

vulnerability is understood to be a shared constitutive condition that evokes our needful openness to others and the open-ended nature of the human condition; it therefore points to power, injury and suffering, as much as it does to forms of care, social (inter)action and cooperation. ${ }^{15}$ For our purposes, the notion of vulnerability becomes even more salient when we examine the forms of reciprocity, responsiveness and interdependence that we argue underpin Habermas's account of language-use, discourse and communicative action.

\subsection{Vulnerability and Communication}

A number of interpreters have questioned whether Habermas's critical theory is up to the task of accounting for various forms of power and subordination even within the normative account of communicative action. We argue that an alternative way of considering these issues and Habermas's theory more generally, is through a consideration of the potential vulnerabilities associated with speech and communicative action, specifically those related to power, injury and harm.

Thomas McCarthy, Amy Allen, and Nancy Fraser, to name a few, have drawn attention to the inadequacy of Habermas's critical theory in terms of accounting for forms of injury and harm associated with racial and gender subordination, for example. As Allen puts it, one major concern is that 'communicative action screens power out of the lifeworld', and as a consequence, adequate consideration is not given to the forms of subordination that are 'reproduced in the lifeworld domains of culture, society and personality' (Allen, 2007, p. 641), forms that are subsequently replicated in speech acts. McCarthy suggests that the resources for tackling these issues might be more readily found in Habermas's early work, where he more fully considers 'the relation between power, social practices and subjectivity' (McCarthy, 2001, p. 654 [cited in Allen (2007)]), or patterns of socialisation that impact on forms of communicative interaction. However, when Habermas moves to advance a formal pragmatic analysis of communication as well as his later theory of discourse ethics, it seems these insights drop away.

15 This way of phrasing the point is in Petherbridge (2016; 2018); that work provides a fuller account of the material on vulnerability. Sections of the material presented here in sections two and four have also been explored in Petherbridge (2021), but in the context of exploring the notions of recognition and trust. 
Following McCarthy's insights, Allen suggests that one of the key problems for Habermas in the development of his formal pragmatics and later theory of communicative action, is the lack of an account of socialisation processes in the lifeworld that consequently adversely impact upon his critical theory of communication. For our purposes, this also points to one of the key sites of vulnerability in communicative practices more generally. As we will discuss below, this is also linked to a second but related form of vulnerability in speech practices, that is, the constitutive power of language in subject-formation, as well as the inherently vulnerable dynamic between speaker and hearer in speech acts.

Habermas's most developed attempt to address the problem of power and subordination in relation to forms of communication, can perhaps be found in his account of systematically distorted communication. He briefly discusses this phenomenon in The Theory of Communicative Action Volume 1, where he describes it as a form of concealed strategic action. As mentioned above, Habermas claims that perlocutionary acts represent forms of strategic action given their intent is to bring about some particular end, rather than merely a form of communicative action directed toward mutual understanding. Habermas argues the following:

[systematically distorted] communication pathologies can be conceived of as the result of a confusion between actions orientated to reaching understanding and actions orientated to success. In situations of concealed strategic action, at least one of the parties behaves with an orientation to success, but leaves others to believe that all the presuppositions of communicative action are satisfied. This is the case of manipulation ... in connection with perlocutionary acts... [Furthermore,] [i]n such cases at least one of the parties is deceiving himself about the fact that he is acting with an attitude orientated to success and is only keeping up the appearance of communicative action. (Habermas, 1984, pp. 332-33)

In other texts, Habermas more directly links the problem of systematically distorted communication to the background context of the lifeworld and the problem of individual development. As Allen identifies, in his 'Reflections on Communicative Pathology' (1974), Habermas examines the phenomena of systematically distorted communication in regard to both the differentiation and connection between 'the external organisation of speech - roughly, its social context - and the internal organisation of speech - the universal and necessary presuppositions of communication' (Allen, 2007, 


\section{Paul Giladi and Danielle Petherbridge}

p. 645). As Allen has argued, this means we might also need to take account not only of systematically distorted communication but the forms of distorted subjectivity that arise in individual development that in turn impact on participants in communication.

For Habermas, though, the consequences of systematically distorted communication refer not only the disruptive effect they have on the social context in which speech acts take place, but also to the very 'validity basis of speech' itself. In this sense, Allen notes '[c]ommunication becomes systematically distorted when the external organisation of speech is overburdened, and this burden is shifted onto the internal organisation of speech' (Ibid.). This dynamic, however, occurs 'surreptitiously', in Habermas's view, without leading to a break in communication or to 'openly declared ... strategic action' (Habermas, 2001, p. 147 [cited in Allen (2007)]). The validity basis of speech is disrupted if at least one of the three universal validity claims - truth, normative rightness or sincerity - are violated even though communication nonetheless continues on the 'presumption' of it being communicative action orientated to reaching understanding, when in fact it conceals the speaker's strategic intent.

In this context, then, we suggest that Habermas's discussion and acknowledgement of the phenomena of systematically distorted communication discloses the kinds of vulnerability inherent not only in being a participant (speaker or hearer) in a speech act but also to the vulnerability contained in communicative action itself. This is the case both in relation to the vulnerabilities inherent to the identity development of subjects who enter into communicative acts such that the organisation of the social context impacts on the internal organisation of speech, but also to the vulnerability and unpredictability that might play out in speech acts themselves.

As the discussion of systematically distorted communication reveals, speech and communication are, then, subject to at least two kinds of vulnerability. Communicative practices are subject to a kind of vulnerability that is implicit to speech acts themselves, in the sense that not only the social context in which speech acts take place are vulnerable to relations of power relations, injury and harm, but the very validity of speech becomes vulnerable. As we will discuss further below, this is played out in the basic dynamics of speech acts themselves, where there is a vulnerability embedded in the basic relation between a speaker's performance and a hearer's response, such that certain conditions enable or constrain speech acts and are impacted upon by the 'situated identities of the persons' 
speaking and hearing. ${ }^{16}$ In this sense, as Allen suggests, '[w]hen Habermas relates the concept of systematically distorted communication to the formation of identity' (Allen, 2007, p. 645), another tension is revealed. This is because for Habermas, as for other critical theorists such as Judith Butler and Axel Honneth, identity is constituted through intersubjective recognition.

However, as both Honneth and Butler reveal, the granting of recognition is inherently vulnerable; the intersubjective basis of subject-formation creates certain kinds of dependence on others but there is no guarantee that recognition will be forthcoming or when it might be withheld. As Habermas himself identifies, this means that systematically distorted forms of identity indicate 'an asym-metrical distribution of power', and this dynamic is shifted onto the 'internal structure of speech' (Habermas, 2001, p. 147 [cited in Allen (2007)]). However, despite this acknowledgment, Habermas does not give due consideration to the way in which speech or language itself may also contribute to distorted forms of identity (for example, through 'interpellation', as Butler puts it).

In the preceding discussion, then, we have so far identified the following forms of vulnerability in relation to speech and communication: 1. The first manifestation of vulnerability is one associated with: identity-formation, which, for Habermas, can be understood in terms of recognition. In this regard, we identified the way in which socialisation processes and forms of power reproduced in the lifeworld domains of culture, society and personality, render subjects vulnerable to distorted forms of identity which in turn impacts upon speech acts. This points not only to the vulnerability associated with recognition as intrinsic to subject-formation but to the constitutive power of language in subject-formation.

2. Such distorted forms of identity-formation may in turn impact upon the internal organisation of speech, leading to increased vulnerability. This is not only the case in terms of the social context in which particular speech acts take place but impacts on the very validity of speech itself.

3. This may play out directly in speech acts and the vulnerability associated with being a participant in communicative action, or in terms of the uncertainty about whether one's speech act is successful or not. This form of vulnerability is inherent to 


\section{Paul Giladi and Danielle Petherbridge}

the relation between a speaker and listener, particularly in relation to the dynamic between a speaker's performance and a hearer's uptake.

We will now turn to a more detailed examination of the vulnerability entailed in the dynamics of speech acts and the potential for disruption or instability to the meaning and effect of such acts.

\subsection{The Vulnerability of Speech Acts: Speaker Performance and Hearer Uptake}

As discussed above, Habermas draws on Austin's analysis of speech acts in developing his account of communication and discourse, where the account of illocutionary acts is central to the theory of communication action (and the discourse theory of ethics). However, as we also saw, vulnerabilities were also identified in relation to inequality and power that distort the internal organisation of speech.

The interrelation between the performative nature of speech and inequality has been more fully addressed by philosophers such as Jennifer Hornsby and Rae Langton. Although these debates have seemingly not included a discussion of vulnerability as inherent to speech acts, we wish to draw attention here to this neglected aspect in the discourse here. Hornsby and Langton have highlighted the way in which, as speakers, certain people suffer what they term 'illocutionary silencing'. As they put it, 'people are silenced when they are prevented from doing certain illocutionary things with words. People who utter words but fail to perform the illocution they intend may be silenced' and this produces what they term 'illocutionary disablement'. In this scenario, a person's speech maybe said to 'misfire' and a person 'is deprived of illocutionary potential' (Hornsby and Langton, 1998, p. 21).

We would like to suggest that this kind of illocutionary silencing illustrates the kinds of vulnerability inherent to speech acts, and by extension, to communicative action. If there is uncertainty about whether a speaker's speech may misfire or be taken-up by a hearer, this causes certain vulnerabilities as a participant in communication. Here it is worth examining the dynamics of the vulnerabilities associated with illocutionary acts that Hornsby and Langton implicitly allude to in terms of their account of illocutionary silencing in more detail.

In many respects, Hornsby and Langton's reading and development of Austin's speech act theory accords with some of the basic interpretations also offered by Habermas. Hornsby and Langton point to the slightly unstable differentiation Austin marks out between 
illocutionary and perlocutionary acts, which in regard to the former, rest on 'the saying of certain words such that, in saying those words one performs an action', whilst in contrast the latter refers to 'the saying of words, such that by saying those words other things are done' (Hornsby and Langton, 1998, p. 24). As Hornsby and Langton remark (Ibid.), however, given that Austin ties illocutionary acts to a hearer's uptake, the outcome of the hearer's responsivity itself could be deemed a kind of consequence.

Nonetheless, like Habermas, Hornsby and Langton want to retain a distinction between illocutionary and perlocutionary acts. This is because, in their view, perlocutionary acts are not merely communicative but, 'introduce the idea of extra-linguistic or incidental consequences of speaking' (Ibid.), in other words, further actions follow from such acts that are not attached to the conventions of speech per se. Importantly, illocutionary speech acts are not only tied to, what Austin terms, 'felicity conditions' associated with certain formal conditions, conventions and institutions, such as an order, request or proposal, that ensure the force of a speech act. They are also related to certain conditions that involve "the institution of language itself' (Hornsby and Langton, 1998, p. 25). In this regard, Hornsby and Langton point to the relation of recognition underlying a speaker and hearer in speech acts and argue that ' $[\mathrm{b}] \mathrm{y}$ involving the hearer as well as the speaker, illocutionary acts reveal language as communicative' (Ibid.).

In this sense, the success or otherwise of illocutionary acts relies upon the hearer's uptake but more generally also requires mutual reciprocity and receptiveness of uptake. As they explain,

$[\mathrm{u}]$ ptake consists in the speaker being taken to be performing the very illocutionary act that, in being so taken, she (the speaker) is performing. Language use then relies in a mutual capacity for uptake, which involves a minimal receptiveness on the part of language users in the role of hearers. This minimal receptiveness does not mean the hearer will agree, or is even capable of agreeing, with what a speaker is saying; but it does mean that a hearer has a capacity to grasp what communicative act a speaker might intend to perform. (Ibid.)

Ultimately, then, mutual reciprocity is required for a speaker's utterance to do the work it means to do, and this brings Hornsby and Langton's view close to the spirit of Habermas's account.

However, in certain cases, this dynamic of illocutionary acts fails because as Hornsby and Langton point out, certain sayings are unspeakable for certain speakers. Some examples they give are, a man 


\section{Paul Giladi and Danielle Petherbridge}

who tries to marry by saying 'I do', only to discover the celebrant was merely an unauthorised actor; or a woman living under Islamic law who wishes to divorce her husband who utters the word 'divorced'. These examples represent what Hornsby and Langton refer to as 'illocutionary disablement' (Hornsby and Langton, 1998, p. 26), in which the saying of something misfires as the speaker does not satisfy certain felicity conditions. Somewhat like Habermas, Hornsby and Langton refer to the centrality of a hearer's recognition of a speaker's intention in order for a speech act to be successful. Furthermore, they also point to the importance of reciprocity for such recognition conditions to be met. In their view, when reciprocity is at work, a hearer recognises the speaker's attempt to perform an illocution, and the speaker's attempt is performed. For example, in the situation of an unwanted sexual advance, a speaker says 'no' and the hearer recognises this as a refusal. ${ }^{18}$ It is precisely when this kind of reciprocity fails and a speaker's illocution is not recognised for what it is, that a speaker is exposed to a particular form of vulnerability as she is unable to do things with words in the manner of successful illocution.

In a related manner, $\mathbf{D}$-becca Kukla has also drawn attention to the way in which a 'speak $\overline{\vec{r}}$ membership in an already disadvantaged social group makes it difficult or impossible for her to employ discursive conventions in the normal way, with the result that the performative force of her utterances is distorted in ways that enhance disadvantage' (Kukla, 2014, p. 441). ${ }^{49}$ However, Kukla questions how convincing it is to maintain a strict differentiation between illocutionary and perlocutionary acts. The argument is that sometimes the full force or consequences of an illocutionary act are not known or do not materialise in the act of speaking itself. Rather, as Kukla points out, recognition of the Other as a speaker as well as the form of responsiveness required for hearer uptake, in their view, do not seem solely intrinsic to illocution but are a perlocutionary effect.

The claim is that it is not really until people respond to a speech act that it can be deemed fully completed. It is only at this point that the effects of a speech act are really known, and in Kukla's view, this needs to be considered an 'integral part of the entire context of the utterance' (Kukla, 2014, p. 454). In other words, various norms and conventions contribute to determining not only whether a speaker is entitled to speak, but 'in placing that performance in social space

18 Viz. Hornsby and Langton, 1998, pp. 27-28.

19 Quill Kulkla writes as Rebeeca Kulkla. See references for details. 
after it is complete' (Kukla, 2014, p. 443). Moreover, certain sayings or words might be 'out of one's control' and vulnerable to what Kukla helpfully terms a form of 'discursive injustice' (Kukla, 2014, p. 445; 441). As Kukla explains, '[v]ictims of discursive injustice are, in virtue of their disadvantaged social identities, less able to skilfully negotiate and deploy discursive convention as tools for communication and action than others' (Kukla, 2014, p. 445). In this regard, Kukla draws attention not only to the recognition condition of a speech act that underpins Hornsby and Langton's view of the necessity of the recognition of a speaker's intention, but also to the impact such an act has in social space more generally. ${ }^{20}$

The types of illocutionary silencing that Hornsby and Langton name, and the notion of discursive injustice that Kukla highlights, not only demonstrate the vulnerability of speech and communication, but also have affinities with forms of epistemic injustice and discursive abuse, as we will discuss in Section 3.

However, before discussing these connections, it is important to consider the way in which a hearer might alternatively be vulnerable to injury and harm by way of a speaker's illocution, such that the vulnerability of the hearer is enhanced rather than that of the speaker. As Beata Stawarska suggests, a hearer's uptake not only enables a speech act to function but also 'plays an active role in shaping power relations' (Stawarska, 2017, p. 186), which points to the vulnerable dynamic involved in unjust speech. On one side, as Stawarska argues, some 'sayings have the potential to produce massive harm' (Stawarska, 2017 , p. 185) that may or may not be intended, and on the other side, '[1] anguage users can re-shape the social world by being active listeners to those who have historically been disempowered' (Stawarska, 2017, p. 186), and whose illocutions often remain unrecognised. As Stawarska, suggests, 'we therefore need to expand the horizon' of communicative acts, 'to include the inherited social conditions of power and the received histories of the said words and the situated identities of the person's saying and hearing them' (Stawarska, 2017, p. 185).

Austin had already pointed to the way in which only those persons delegated with authority could successfully perform certain illocutionary acts, recognising that such authority whether celebrant or divorcee, is underwritten by an entire social order. However, Stawarska argues that historically disempowered or de-authorised groups can also come to 'make words speak somewhat differently than they did in the past' (Stawarska, 2017, p. 190). This requires recognising that linguistic meanings and language use are themselves vulnerable 


\section{Paul Giladi and Danielle Petherbridge}

to change, in the sense that they have a certain 'socially contingent plasticity' (Ibid.) that has the potential to rupture inherited and sedimented meanings and usage.

There is, then, a two-pronged response to the phenomena of disempowered communicative participants: (1) there is what Stawarska, following Butler, refers to as the 'transgressive reclamation of socially harmful speech' by re-orientating the use and signification of certain words. In this manner, harmful or injurious speech can be turned around such that it becomes 'an empowering emancipatory practice' (Ibid.). This is the ease with words such as 'queer' or 'black'. In such cases, subordinated groups are themselves 'empowered to negotiate what words signify and what effects they may produce' (Ibid.). Thus, where once the saying of particular words might have been injurious, in the act of reclaiming them, disempowered groups are able to re-orientate the meaning and the affects that words produce in a self-affirming manner, and this also shifts the authority problem in linguistic encounters. ${ }^{21}$ (2) Extending insights from Hornsby and Langton, this shift not only requires an alteration in terms of who has authority to speak, but also requires a form of 'active heeding' that enables forms of 're-authorisation' (Ibid.). Thus, akin to Hornsby and Langton, as Stawarska argues, the 'process of re-authorisation vitally depends on cultivating a stance of productive listening that empowers the utterance to become felicitous by virtue of the recognition it bestows upon the speaker' (Stawarska, 2017, p. 192).

Thus, the kind of vulnerability we wish to highlight is played out at what Stawarska terms the 'micro-level' of linguistic encounters, and this is particularly impacted by power relations between communicative partners to interaction. ${ }^{22}$ The forms of vulnerability we refer to, then, include not only forms of injury and harm that can be inflicted through speech acts, but also the uncertainty and unpredictability of the receptive uptake of a hearer to the illocutionary acts of subordinated groups, as well as the vulnerability of the meaning of such speech acts themselves, which might be resisted, reclaimed, and negotiated. ${ }^{23}$ Taking-up and extending the insights discussed above in relation to the notions of illocutionary silencing and discursive injustice, in what immediately follows, we focus on elaborating epistemic pathologies in the context of epistemic oppression and testimonial injustice.

$\begin{array}{ll}21 & \text { Viz. Stawarska }(2017, \text { p. 190). } \\ 22 & \text { Viz. Stawarska }(2017, \text { p. 191). } \\ 23 & \text { See Stawarska (2017, p. 191). }\end{array}$ 


\section{Epistemic Pathologies: Epistemic Oppression \& Testimonial Injustice}

Epistemic oppression refers to, as Kristie Dotson writes, 'a persistent and unwarranted infringement on the ability to utilise persuasively shared epistemic resources that hinders one's contributions to knowledge production' (Dotson, 2014, p. 115). According to Dotson, systemic practices of epistemic exclusion and oppression result in positions and communities that produce deficiencies in social knowledge, as evidenced by increasingly widespread, normalised virulent epistemic contempt for non-privileged groups. For example, distress at systemically reproduced institutional racism and police brutality is often dismissed, to the extent that the vocabulary of protest against racial oppression is viciously misrecognised to the point of erasure. As Robert Gooding-Williams writes, the reactionary view is 'a failure to regard the speech or actions of black people as manifesting thoughtful judgements about issues that concern all members of the political community' (Gooding-Williams, 2006, p. 14).

Black Lives Matter demonstrations typically involve the chant 'Hands Up, Don't Shoot!', where marchers raise their hands above their heads while chanting, as part of the effort to explicitly challenge the reactionary socio-epistemic paradigms which construe antiracist protestors as public threats. To quote José Medina here, ' $[\mathrm{t}] \mathrm{his}$ slogan performatively challenges the misplaced presumption that demonstrators pose a threat to public order, interrogating the underlying narratives that depict them as such a threat, while invoking alternative images of peaceful expressions of group agency' (Medina, 2018, p. 12). Furthermore, the chants 'Whose streets? Our streets!' and 'No Justice, No Peace!' are deliberately misinterpreted and misrecognised by reactionary groups to imply that the basic progressive claim 'black lives matter' is equivalent to 'black lives matter more than white lives'. Crucially, this forms a significant part of the explanation for why \#AllLivesMatter is in fact reactionary, since \#AllLivesMatter reveals itself as ignorant of structural racism and systemic misrecognition.

Related to, but conceptually and politically distinct from the concept of epistemic oppression, which is principally concerned with endemic patterns of structural exploitation and domination of specific epistemic communities, is the concept of epistemic injustice. To quote Miranda Fricker, epistemic injustice arises when a person is 'wronged in their capacity as a knower' (Fricker, 2007, p. 20). Such wronging usually happens in at least two ways: (1) through testimonial injustice, which typically occurs when a speaker's assertions are 


\section{Paul Giladi and Danielle Petherbridge}

given less credibility than they deserve because the hearer has prejudices about a social group of which the speaker is a member; ${ }^{24}$ (2) through hermeneutical injustice, which occurs when there is a gap in the collective interpretive resources of a given society that leaves a marginalised and socially powerless group unable to properly make sense of their social powerlessness. Crucially, the epistemic pathologies of misrecognising or not recognising individual knowledge-claims and/or social group knowledge-claims are particularly vicious forms of humiliation, in that they are a 'deformation of the normal human capacity for the evaluative perception of others' (Zurn, 2015, p. 101).

With regard to the kind of epistemic pathology of recognition in the context of testimonial injustice, in particular (for our specific focus here), it would be helpful to refer to Patricia Williams's autobiographical account of her experience of testimonial justice:

I was shopping in Soho [in Benetton's] and saw a sweater that I wanted to buy for my mother. I pressed my round brown face to the window and my finger to the buzzer, seeking admittance. A narrow-eyed, white teenager ... glared out, evaluating me for signs that would pit me against the limits of his social understanding. After about five seconds, he mouthed 'We're closed', and blew pink rubber at me. It was two Saturdays before Christmas, at one o'clock in the afternoon; there were several white people in the store who appeared to be shopping for things for their mothers. I was enraged ... In the flicker of his judgemental grey eyes, that sales-child had transformed my brightly sentimental, joy-to-the-world, pre-Christmas spree to a shambles ... $[\mathrm{H}]$ is refusal to let me into the store ... was an outward manifestation of his never having let someone like me into the realm of his reality ... (Williams, 1991, pp. 44-56)

A rumour got started that the Benetton's story wasn't true, that I had made it up, that it was a fantasy, a lie that was probably the product of a diseased mind trying to make all white people feel guilty. At this point I realised ... that the greater issue I had to face was the overwhelming weight of a disbelief that goes beyond mere disinclination to believe and becomes active suppression of anything I might have to say. The greater problem is a powerfully oppressive mechanism for denial of self-knowledge and expression. And this denial cannot be separated from

24

See Davis (2016) and Giladi (forthcoming) for how credibility excess is an act of epistemic injustice. 
the simultaneously pathological willingness to believe certain things about blacks - not believe them, but things about them. (Ibid., p. 242)

In addition to being harmed by the salesperson's racism - Williams was racially barred from entry and consequently could not participate in the activity of buying Christmas presents for one's mother Williams suffered a distinct, further wrong by having her testimony dismissed and not accorded serious communicative status. Specifically, in the Habermasian sense of validity claims involved with those speech acts conveying truthfulness and, above all, revealing and baring the subjective world of individual anxieties, hopes (and the like) to one's listener(s), Williams, rather than automatically receive the default level of epistemic respect, trust, and communicative appreciation provided by the Acceptance Principle, ${ }^{25}$ is not only treated with epistemic scorn, she is also stripped of any normative authority. She is deemed as someone who violates the communicative norms of assertion. As such Williams's capacity for speech is violated - where, crucially, speech involves the vulnerability that comes with revealing oneself in the transparent communicative act of sharing sincere propositional content for uptake by the listener. This is why racism - at the epistemic level - is structured around the pathological norm of believing untrue things about black people, rather than believing black people about true things.

Testimonial injustice deprives Williams, a rational agent, of her rightful place as someone moving in the communicative space of reasons, and thereby leaves individuals like her who are systemically prejudiced against in a state of self-alienation and double-consciousness: Williams is forcibly alienated from her own speech and rationality, where these enable her to be a member of a community of inquirers and reliable narrators. As part of her self-conscious identification with fellow African-Americans in an African-American community, Williams communicatively self-interprets and finds such communicative action empowering. However, African-Americans (and other people of colour), as part of a racist world, are met with external and hostile web of meanings that radically distort such uplifting local self-conceptions. The power structure of racial oppression is pervasive such that the experiential relation Williams has to herself becomes distorted by how she views her agency from the perspective of white prejudicial attitudes, which aim to rob her of her position as a communicative subject, and instead treat her as an object of derision 


\section{Paul Giladi and Danielle Petherbridge}

and contempt. This is what we take her to mean when she argues that 'the greater problem is a powerfully oppressive mechanism for denial of self-knowledge and expression'. Crucially, the asymmetrical nature of the cognitive environment causes Williams to think and feel that the space of reasons, where communicative practices derive their sense of meaning and purpose, is not a space for her.

Given that epistemic oppression and testimonial injustice cause one to be alienated from both their own communicative rationality and from the speech-based practices which necessarily constitute discourse between peers, exclusion from the space of reasons amounts to 'discursive abuse'. The experience of discursive abuse 'carries with it the danger of an injury that can bring the identity of the person as a whole to the point of collapse' (Honneth, 1995, pp. 132-33), where the identity under threat here is a person's self-interpretation as agen$t_{i a l}{ }^{26}$ since speech involves vulnerability with respect to revealing oneself in the transparent, trusting communicative act of sharing propositional content for uptake by the listener. To use Andrea Lobb's expression, the kind of 'epistemic injury' (Lobb, 2018, p. 1) endured here can be made sense of in relation to what Richard Rorty calls 'mute despair' and 'intense mental pain'. For Rorty, this notion of agential pain - the type of pain unique to agents

-reminds us that human beings who have been socialised ... can all be given a special kind of pain: they can all be humiliated by the forcible tearing down of the particular structures of language and belief in which they were socialised (or which they pride themselves on having formed for themselves). (Rorty, 1989, p. 177)

The failure to properly recognise and accord somebody the epistemic acknowledgement they merit is an act of abuse in the sense of forcibly depriving individuals of a progressive communicative environment in which the epistemic recognition accorded to them plays a significant role in enabling and fostering their self-confidence as a communicative agent. This includes:

i. External and forcible control over one's own communicative integrity.

ii. Violation of communicative integrity prevents one from trusting others and one's own capacities to the distressing extent that victims internalise culpability.

iii. Discursive abuse represents a type of disrespect that does lasting damage to one's basic confidence that one can 
autonomously coordinate one's own communicative claims and even identify as a communicative subject or be recognised as one.

Understood in this manner, there is compelling reason to see how all three points above relate to the vulnerability associated with a) identity-formation, b) distorted identity-formation and the internal organisation of speech, and c) being a participant in communicative action, where c) especially concerns the dynamic between a speaker's performance and a hearer's uptake. Regressive recognition orders deliberately exploit intersubjective vulnerability and pervert communicative dynamics by making those excluded from the space of reasons think and feel as though their rejection is entirely the result of their failings. Epistemic oppression and systemic testimonial injustice permeate, to the extent that individuals and/or social groups are made to blame themselves for not being deemed worthy enough to be afforded credibility. ${ }^{27}$

\section{Spreading One's Dreams at the Feet of the Other: Habermas and the Fragility of Communicating Subjects}

The preceding discussion of illocutionary acts and silencing, as well as discursive injustice and abuse, raises questions about the neglected element of vulnerability inherent in being a participant in speech acts and more fully in communicative action. In turn, the vulnerability of participants in communicative action, flows through to the vulnerability of persons as knowers and participants in the space of reasons. What, then, do we draw from the above discussion in regard to the interrelation between vulnerability, speech and communication as it pertains to Habermas's work? In what follows, we conclude by considering, on the one hand, the manner in which an account of vulnerability enriches Habermas's overly formal notions of communicative action and discourse; on the other, we examine the ways in which Habermas's own account of communicative action is already oriented towards the vulnerability of speaking agents. This is evinced not only through the rules of communication and discourse that he goes to such lengths to construct, but also in claims he makes in regard to moral intuitions and discourse ethics.

As we have seen, Habermas builds an account of normativity and recognition into his theory of communicative action and discourse.

27 For previous articulations of these points in section three, see Giladi $(2018,2020)$. 


\section{Paul Giladi and Danielle Petherbridge}

Implicitly, the formal structure of Habermas's theory of discourse and notion of the 'ideal speech situation', already acknowledges the vulnerability of speaking agents by providing measures aimed to protect persons in the realm of communicative action. His account of language-use points to what he regards as our primordial interdependence as language-users and the basic uncertainty of this endeavour. The account of the ideal speech situation makes a claim for equality of speaking-agents by having the opportunity to speak and to express one's viewpoint without coercion or interference. Moreover, Habermas argues for the need for free and equal argumentation and the use of reason in practical discourse, with the view to reaching mutual understanding and fostering mutual cooperation. However, he does not assume this process is seamless. Rather, he points to the fragilities and uncertainties of communicative freedom that arise with modernity due to particular developmental logics or dynamics (the decoupling of 'Lifeworld' and 'System'28), which in turn impact upon the internal structure of communicative action and the potential for rationality.

Notably, Habermas explicitly ties his account of discourse to a notion of vulnerability in texts such as Moral Consciousness and Communicative Action. In this text, he restates that '[a]rgumentation insures that all concerned in principle take part, freely and equally, in a cooperative search for truth, where nothing coerces anyone except the force of the better argument' (Habermas, 1990, p. 198). However, what is significant in this account is that Habermas also makes clear the anthropological claim underlying his discursive approach as it pertains to moral intuitions. As he writes:

Moral intuitions are intuitions that instruct us on how best to behave in situations where is it in our power to counteract the extreme vulnerability of others by being thoughtful and considerate. In anthropological terms, morality is a safety device compensating for a vulnerability built into the sociocultural form of life. (Habermas, 1990, p. 199)

Here, it might be suggested, that Habermas makes clear that his theory of communicative action is in fact underpinned by a constitutive notion of vulnerability that is inherent to every social and

28 Habermas makes a distinction between what he terms the 'Lifeworld', which refers the normatively underpinned public sphere as well as the private sphere of family life, in contrast to what he terms 'System', which includes the State and the activities of market capitalism steered by purely formal or instrumental mechanisms. See Habermas (1987a). 
intersubjective context. It also brings Habermas within the vicinity of other vulnerability theorists when he ties this notion of vulnerability to our constitutive interdependence as human beings and to forms of subject-formation dependent upon recognition from others. For, as he states: ' $[\mathrm{t}] \mathrm{h}$ mo more the subject becomes individuated, the more he becomes entangled in a densely woven fabric of mutual recognition, that is, of reciprocal exposedness and vulnerability' (Habermas, 1990, p. 199).

In Habermas's view, then, moralities address or respond to what he terms the 'fragility of human beings individuated through socialisation' (Habermas, 1990, p. 200). But the protection of these fragilities requires a two-pronged approach that safeguards not only the individual subject but also the community in which that subject is embedded in a web of 'intersubjective relations of recognition' (Ibid.). These two elements point to two related principles that Habermas terms 'justice' and 'solidarity', and as he sees it, both principles are rooted in 'the specific vulnerability of the human species, which individuates itself through sociation' (Ibid.). In this respect, we argue that Habermas's theory should be taken seriously as a contribution to the discourse on vulnerability, particularly as it pertains to the neglected elements of speech and communication. In the essay 'Morality and Ethical Life', he even goes so far to say that 'linguistically mediated interaction, is both the reason for the vulnerability of socialised individuals and the key resource they possess to compensate for that vulnerability' (Habermas, 1990, p. 201). It is clear, then, that Habermas acknowledges that forms of vulnerability are inherent to speech and linguistically mediated interaction as well as to individual subject-development.

However, despite this anthropological claim in regard to linguistic forms of vulnerability, the way in which Habermas addresses this issue is ironically conceptualised at a rather formal and abstract level. As a consequence, he does not take adequate account of the more embodied, pre-reflexive and affective forms of interaction that characterise much of the literature in vulnerability theory. Indeed, even in his early work, Habermas's theory is based on the assumption that certain procedural rules are always already presupposed by human discourse and that these rules can be drawn on to validate moral principles, and thus normatively justify social interaction. Under this schema, rational consensus presupposes an ideal speech situation as a kind of meta-norm, a situation that significantly assumes a kind of symmetry and reciprocity, requiring all participants to adopt the standpoint of the 'generalised other'. In assuming this standpoint, though, participants must abstract from their 


\section{Paul Giladi and Danielle Petherbridge}

individuality and concrete identity, thereby leaving behind their private and particular affiliations, and the specific social context in which they are embedded. ${ }^{29}$ Through such a principle, Habermas suggests a rational consensus can be achieved in the context of conflicting opinions and interests regardless of differing traditions, cultural perspectives, or individual life-histories.

In order to make this claim, though, Habermas's moral theory relies upon a distinction he makes between issues of justice (morality) and questions of the good life (ethics), based upon a postmetaphysical argument shared with John Rawls's liberal egalitarianism (1971; 1985) that ontological questions must be separated from practical matters if the universalist normative presuppositions of communicative rationality are to succeed. In this respect, in Habermas's view, moral judgements are concerned only with right or just action, not with substantive values of the good or characteristics that pertain to individual needs and identities; only claims about rightness and just action are considered to provide norms that are obligatory for all persons universally and equally. ${ }^{30}$ As a consequence, Habermas concludes that moral-practical dilemmas can be resolved on the basis of a universal sense of communicative reason, whereas questions relating to ethical identities can only be considered in terms of the ethical values within a particular form of life.

However, as Honneth, for example, has argued, normative claims are experienced and articulated by people in everyday life as disturbances that may, or may not, make mutual recognition possible prior to them reaching the level of discourse. These disturbances may therefore disclose the processes through which recognition is, or is not, achieved prior to the articulation of moral norms. Consequently, these are processes and conditions that individuals must feel are safeguarded even before they can attain the competency considered necessary by a theory of discourse ethics. In this respect, then, the Habermasian form of moral reasoning, as the impartial application of general principles, describes a restricted field of moral life concerned with public institutional forms of morality, but which, ironically ignore everyday motivational contexts despite their explicitly pragmatic orientation. ${ }^{31}$ The universalist principle of Habermas's discourse ethics demands from interaction partners

29 See Benhabib (1986). For a full account of the argument outlined here, see Petherbridge (2013).

30 See Rehg (1994).

31 Viz. Honneth (1995). See also Petherbridge (2013) a full account of this argument. 
a willingness and refined ability to enable consideration of normative questions from a generalised standpoint whilst leaving aside their concrete relations with others in everyday experience. ${ }^{32}$ However, such claims address dilemmas in social life that are not located at the abstract level of universalisation, but at the concrete level at which everyday forms of conflict occur. The proceduralism of Habermas's discourse theory and his overly formal account of linguistic action, therefore, means it is difficult to theorise how the initial feelings of injury that motivate moral claims are converted into propositional attitudes (articulated linguistic claims) in the first place.

As the above discussion of Allen revealed, it is then not only a matter of identifying forms of systematically distorted communication but equally forms of systematically distorted identity-formation that impact upon forms of communication. Thus, as Honneth and Allen have noted, normative criteria must not only be concerned with the intersubjective presuppositions of language but also the intersubjective presuppositions of human identity development that impact upon speech, communication, and the social scaffolding of the knower. Moreover, as Honneth identifies, Habermas's theory is also susceptible to the 'cultural exclusion' of oppressed social classes from the articulation of claims of injustice in the public sphere. Honneth draws attention to the silencing of forms of moral conflict or social feelings of injustice, that as he expresses it in early work, 'lie behind the façade of late-capitalist integration' (Honneth, 1995, p. 207).

This critique is aimed at Habermas's particular model of society and the public sphere, which unwittingly results in the exclusion of certain voices and forms of moral protest from the public field of speech and communicative action; in other words, Habermas's model fails to make sufficient sense of this type of discursive abuse, where such forms of discursive abuse reinforce the structural (epistemic) obstacles facing certain voices and forms of moral protest. These structural (epistemic) obstacles prevent certain voices and forms of moral protest from being publicly articulable and from becoming fully elaborated moral claims (Honneth, 1995, p. 207; p. 209). In this manner, forms of exclusion are related to deprivation of 'linguistic and symbolic means' (Honneth, 1995, p. 213), and this creates not only misrecognition and silencing, but the invisibilisation of disadvantaged groups. Indeed, what particularly motivates the inquiries of intersectional feminist epistemologists is precisely the focus on (i) the power dynamics of gender, race, class, sexuality, and disability; (ii) the role these dynamics of power play in the social conditions of

Viz. Benhabib (1986, pp. 320-21). 


\section{Paul Giladi and Danielle Petherbridge}

knowing; and (iii) the ways in which the structures of existing social institutions affect the actual practices of knowers. As indicated above, intersectional feminist epistemologists are particularly concerned with (i) how the normative space of reasons is organised; (ii) how one negotiates the normative space of reasons; and (iii) how one gets into normative space at all. To put this more simply, the overriding focus is critically uncovering the substantive link between various types of power relations and epistemic practices. Arguably, the central question is 'who gets to know things?'.

One problem, then, with Habermas's 'linguistification' of moral conflict and his account of justice, is that it potentially contributes to the very forms of silencing it seeks to overcome. This is due not only to the formal nature of his pragmatics but also implicit assumptions about the skills and capacities required for individuals and groups to enter into moral debate and discourse in the first place. Moreover, Habermas's account of communicative action and discourse relies upon certain democratic and discursively structured institutions and forms of political life. Here Habermas points to an important issue: communication free from power and distortion requires the establishment of robust modern democratic institutions, ones that are constituted through reciprocal relations and patterns of interaction. Such institutions must be underpinned by forms of reciprocal freedom that are grounded in relations of recognition. For such institutions to ensure forms of communicative action without coercion they must be immanently constituted from within the structure of recognition relations, or to put it another way, they must develop out of normative patterns of social interaction between social actors themselves in any given social context. ${ }^{33}$

Unfortunately, many existing modern institutions fall well short of the standards of Habermasian discourse and forms of recognition: they tend to have exclusionary epistemic habits and reveal a normalised contempt for non-privileged agents. To put this point more polemically, many existing modern institutions fail to be relational institutions, since they fail to promote practices of symmetrical recognition in communication; many institutions have substantive internal structural weaknesses; they often fail to encourage the quest for selfrealisation and thereby leave people who are epistemically oppressed and marginalised in a constant state of alienation; many existing modern institutions, therefore, require radical change, rather than liberal tweaks. The goal of social critique, therefore, is to identify and shift unequal power relations that are directly responsible for

33 See Honneth (2014). 
forms of suffering and alienation that are produced by marginalisation and thereby further entrench forms of oppression.

On this score, Habermas's theory offers insights into the ways in which such institutions might be structured democratically in a manner that enables equal participation in communicative interaction. For, as Simone Chambers points out, in principle, discourse ethics combats the 'marketplace of ideas between elites in which interests and understandings compete with each other for domination' (Chambers, 1995, p. 176). Habermas's discourse theory (in principle) offers a model for mutual cooperation precisely through the acknowledgement of difference. These discursive spaces, however, can be opened up further by extending 'opportunities to participate, by including excluded voices, by democratising media access, by setting up 'town meetings', by politicising the depoliticised, by empowering the powerless, by decentralising decision-making ... and so on' (Chambers, 1995, pp. 176-77). These are all measures that might reinvigorate practices of discourse that are at the heart of Habermas's democratic project and address the fragilities associated not only with being a participant in communicative action but also interdependent subjects who rely upon recognition from others.

For as we have argued, participants in communication lay themselves bare in front of one another, and as Habermas suggests, there is an implicit trust built into communication that aims at reaching understanding. By drawing attention to the structure of communication with respect to the subjective world, Habermas highlights the need for the recognition of the intentions of the speaker in acts of communication. In doing so, he acknowledges the forms of interdependence, reciprocity and responsiveness that are intrinsic to vulnerability in a manner that might evoke an account of the intentions of the horizontally 'inclined', rather than vertically 'autonomous' speaker, to use Adriana Cavarero's terms. ${ }^{34}$

The desire to transform the practices of many existing modern institutions by recognising and embracing vulnerability crucially reminds us of precisely what we owe to one another. As evoked by the passage from Yeats with which this paper began, as communicating subjects, we 'spread our dreams' before one another thereby placing our trust in the other's moral responsiveness. Acknowledging the vulnerable dynamics of discourse advances democratic forms of association by fostering the protection of the individual as well as 'the well-being of the community to which he [or she] belongs' (Habermas, 1990, p. 200). As Habermas writes in one of his more recognitive 


\section{Paul Giladi and Danielle Petherbridge}

moments, as 'creatures' constituted by 'profound vulnerability' we require communicative forms of moral attentiveness by which we can defend both 'the integrity of the individual' and preserve 'the vital ties of mutual recognition through which individuals reciprocally stabilise their fragile identities' (Habermas, 1990, p. 199; 200). Embracing mutual vulnerability, then, has the potential to provide the indispensable symbolic and material space for bringing about a better world.

\section{Manchester Metropolitan University P.Giladi@mmu.ac.uk \\ University College Dublin danielle.petherbridge@ucd.ie}

\section{References}

Amy Allen, 'Systematically Distorted Subjectivity? Habermas and the Critique of Power', Philosophy and Social Criticism 33 (2007), 641-50.

J.L. Austin, How to do Things with Words, eds. J. O. Urmson and Marina Sbisà, $2^{\text {nd }}$ Edition (Oxford: Oxford University Press, 1975).

Seyla Benhabib, 'The Generalised and the Concrete Other: The Kohlberg-Gilligan Controversy', Praxis International 5 (1986), 402-424.

Seyla Benhabib Critique, Norm and Utopia: A Study of the Foundations of Critical Theory (New York, Columbia University Press, 1986).

Robert B. Brandom, Making It Explicit: Reasoning, Representing, and Discursive Commitment, (Cambridge, MA: Harvard University Press, 1994).

Robert B. Brandom Tales of the Mighty Dead: Historical Essays in the Metaphysics of Intentionality, (Cambridge, MA: Harvard University Press, 2002).

Tyler Burge, 'Content Preservation', The Philosophical Review 102 (1993), 457-88.

Judith Butler, Precarious Life: The Powers of Mourning and Violence (New York: Verso, 2004).

Simone Chambers, 'Feminist Discourse/Practical Discourse' in Feminists Read Habermas: Gendering the Subject of Discourse, ed. Johanna Meehan (New York \& London, Routledge, 1995). 
Emmalon Davis, 'Typecasts, Tokens, and Spokespersons: A Case for Credibility Excess as Testimonial Injustice', Hypatia 31 (2016), 485-501.

Kristie Dotson, 'Conceptualising Epistemic Oppression', Social Epistemology 28 (2014), 115-38.

J. G. Fichte, Foundations of Natural Right, ed. Frederick Neuhouser, trans. Michael Baur, (Cambridge: Cambridge University Press, 2000).

Miranda F. Fricker, Epistemic Injustice: Power and the Ethics of Knowing (Oxford: Oxford University Press, 2007).

Paul Giladi, 'Epistemic Exploitation and Ideological Recognition', in Epistemic Injustice and the Philosophy of Recognition, eds. Paul Giladi and Nicola McMillan (New York: Routledge, forthcoming).

Paul Giladi, 'Epistemic Injustice: A Role for Recognition?', Philosophy E Social Criticism 44 (2018), 141-158.

Paul Giladi, 'The Agent in Pain: Alienation and Discursive Abuse', International Fournal of Philosophical Studies 28 (2020), 692-712.

Robert Gooding-Williams, Look, a Negro!: Philosophical Essays on Race, Culture and Politics (New York: Routledge, 2006).

Paul H. Grice, 'Logic and Conversation', in Syntax and Semantics 3: Speech Acts, eds. Peter Cole and Jerry L. Morgan (New York: Academic Press, 1975).

Jürgen Habermas, Knowledge and Human Interests, trans. J. J. Shapiro (Boston: Beacon Press, 1971).

Jürgen Habermas Theory and Practice, trans. John Viertel (Cambridge: Polity Press, 1973).

Jürgen Habermas The Theory of Communicative Action: Volume One. Reason and the Rationalisation of Society, trans. Thomas McCarthy (Beacon Press, Boston, 1984).

Jürgen Habermas The Theory of Communicative Action: Volume Two. Lifeworld and System: A Critique of Functionalist Reason (Beacon Press, Boston, 1987a).

Jürgen Habermas The Philosophical Discourse of Modernity: Twelve Lectures, trans. Frederick Lawrence (Cambridge: Polity Press, 1987b).

Jürgen Habermas 'Morality and Ethical Life: Does Hegel's Critique of Kant Apply to Discourse Ethics?' in Moral Consciousness and Communicative Action, trans. C. Lenhardt and S. Weber Nicholsen (Cambridge, MA: MIT Press, 1990).

Jürgen Habermas Postmetaphysical Thinking, trans. W. M. Hohengarten (Cambridge, MA: MIT Press, 1992). 


\section{Paul Giladi and Danielle Petherbridge}

Jürgen Habermas Between Facts and Norms: Contributions to a Discourse Theory of Law and Democracy, trans. William Rehg (Cambridge, MA: MIT Press, 1996).

Jürgen Habermas On the Pragmatics of Social Interaction, trans. Barbara Fultner (Cambridge, MA: MIT Press, 2001).

Axel Honneth, 'Moral Consciousness and Class Domination: Some Problems in the Analysis of Hidden Morality,' in The Fragmented World of the Social: Essays in Social and Political Philosophy, ed. C.W. Wright (Albany: SUNY Press, 1995).

Axel Honneth The Struggle for Recognition: The Moral Grammar of Social Conflicts, trans. Joel Anderson (Cambridge, MA: MIT Press, 1995).

Axel Honneth Freedom's Right: The Social Foundations of Democratic Life, trans. Joseph Ganahl (Cambridge: Polity Press, 2014).

Jennifer Hornsby and Rae Langton, 'Free Speech and Illocution', Legal Theory 4 (1998), 21-37.

Stephen Houlgate, 'Hegel and Brandom on Norms, Concepts and Logical Categories', in German Idealism: Contemporary Perspectives, ed. Espen Hammer (London: Routledge, 2007).

Immanuel Kant, Anthropology from a Pragmatic Point of View, trans. and ed. R. B. Louden, (Cambridge: Cambridge University Press, 2006).

Rebecca Kukla, 'Performative Force, Convention, and Discursive Injustice', Hypatia 29 (2014), 440-457.

Andrea Lobb, "Prediscursive Epistemic Injury': Recognising Another Form of Epistemic Injustice?' Feminist Philosophy Quarterly 4 (2018 Article 3), 1-23.

Thomas McCarthy, 'Die politische Philosophie und das Problem der Rasse', in Die Öfentlichkeit der Vernunft und die Vernunft der Öffentlichkeit: Festschrift für Fürgen Habermas, eds. Lutz Wingert and Klaus Günther (Frankfurt, Suhrkamp, 2001). G.H. Mead, Mind, Self, and Society: The Definitive Edition, eds. C. W. Morris, D. R. Huebner and H. Joas (Chicago: University of Chicago Press, 2015).

José Medina, 'Misrecognition and Epistemic Injustice', Feminist Philosophy Quarterly 4 (2018 Article 1), 1-16.

Jari I. Niemi, 'Habermas and Validity Claims', International Fournal of Philosophical Studies 13 (2005), 227-244.

Danielle Petherbridge, The Critical Theory of Axel Honneth (Lanham, MD: Lexington Books, 2013).

Danielle Petherbridge 'What's Critical about Vulnerability? Rethinking Interdependence, Recognition and Power', Hypatia 31 (2016), 589-604. 
Danielle Petherbridge 'How Do We Respond? Embodied Vulnerability and Ethical Responsiveness', in New Feminist Perspectives on Embodiment eds. Clara Fischer and Luna Dolezal (Palgrave MacMillan, 2018).

Danielle Petherbridge 'Recognition, Vulnerability and 'Trust', International Fournal of Philosophical Studies, 29 (2021).

William Rehg, Insight and Solidarity: A Study in the Discourse Ethics of Ұ̈̈rgen Habermas, Berkeley, Los Angeles (London, University of California Press, 1994).

Richard Rorty, Contingency, Irony, and Solidarity, (Cambridge: Cambridge University Press, 1989).

Wilfrid Sellars, Science, Perception and Reality, (London: Routledge, 1991).

Beata Stawarska, 'Linguistic Encounters: The Performativity of Active Listening', in Body/Self/Other: The Phenomenology of Social Encounters, eds. Luna Dolezal and Danielle Petherbridge (Albany: SUNY Press, 2017).

Patricia J. Williams. The Alchemy of Race and Rights: Diary of a Law Professor (Cambridge, MA: Harvard University Press, 1991).

Christopher F. Zurn. Axel Honneth: A Critical Theory of the Social (Cambridge: Polity Press, 2015). 